\title{
РЕЛИГИОЗНАЯ ПОЛИТИКА ТИРАНИИ СПАРТОКИДОВ НА БОСПОРЕ
}

\section{RELIGIOUS POLICY OF THE TYRANNY OF THE SPARTOCIDS ON THE BOSPORUS \\ L. Tarasova}

Summary: The article is devoted to identifying the features of the religious policy of the rulers of the Bosporus Kingdom in the last third of the 5th - end of 4th century BC (from Spartok to Perisade I). Based on a comprehensive analysis of narrative, epigraphic, numismatic, and archaeological sources, the following aspects of sacred politics are considered: changes in the pantheon of gods, the evolution of the titles of rulers, and the construction of religious buildings. The author concludes that the changes in religion - the deification of the rulers, the convergence of Hellenic and local deities - make it possible to define the rule of the early Spartocids as a minor tyranny.

Keywords: Northern Black Sea region, Bosporus Kingdom, Spartocid dynasty, tyranny, religious policy.
$\mathrm{B}$ современном антиковедении, выявляя характерные черты древнегреческих полисов, исследователи обращают внимание на весьма значимую роль религии, как в частной, так и в публичной жизни эллинов [23, с. 23-30; 24; 25, 26]. Это соображение относится к полисам не только Балканской Греции, но и периферии античного мира, в том числе эллинским государствам Северного Причерноморья. При этом имели место региональные особенности развития как собственно эллинских полисов, и уж тем более Боспорского царства как греко-варварского государства.

В данной статье рассматриваются особенности религиозной политики ранних Спартокидов, нашедшие отражение в сохранившихся нарративных, эпиграфических, нумизматических и археологических источниках. Анализ религиозной политики, на наш взгляд, позволит более точно дефинировать политический режим, существовавший в Боспорском государстве от Спартока до Перисада I (438-310 гг. до н.э.).

На окраинах античного мира в моменты внутренних кризисов резко усиливалось давление варваров. - Такое сочетание внутреннего и внешнего факторов создавало в колониях благоприятные условия для возникновения авторитарных, тиранических или монархических форм правления. Они развивались быстрее и достигали более полных форм самовыражения, нежели в самой Балканской Греции [28, с. 138]. Не стал исключением и регион

\author{
Тарасова Любовь Валерьевна \\ К.и.н., ФГБОУ ВО «Калужский государственный \\ университет им. К.Э. Циолковского» \\ tarlv@mail.ru
}

Аннотация: Статья посвящена выявлению особенностей религиозной политики правителей Боспорского царства последней трети V - конца IV вв. до н.э. (от Спартока до Перисада I). На основе комплексного анализа нарративных, эпиграфических, нумизматических и археологических источников рассматриваются следующие аспекты сакральной политики: изменения пантеона богов, эволюцию титулатуры правителей, строительство культовых сооружений. Автор делает вывод, что происходившие изменения в религии - обожествление правителей, сближение эллинских и местных божеств - позволяют определить правление ранних Спартокидов как младшую тиранию.

Ключевые слова: Северное Причерноморье, Боспорское царство, династия Спартокидов, тирания, религиозная политика.

Черного моря, где наиболее известны тиранические режимы в Гераклее Понтийской (364/363-281 гг. до н.э.) [18, с. 101-123; 28, с. 150-153] и Синопе (470/460-439/436 гг. до н.э.) $[6$, с. 69].

На северном побережье Понта Эвксинского документально подтверждено существование тираний в Ольвии - в 80-е гг. и в последние десятилетия V века до н.э. и на Боспоре Киммерийском, при ранних Спартокидах. В этом перечне не упомянуты Археанактиды, но, на наш взгляд, правлению этой династии был присущ не тиранический, а олигархический характер: сродни тому, что существовал, по свидетельству Аристотеля, в Аполлонии Понтийской (Pol., V, 2, 11; V, 5, 7) и в Истрии (Pol., V, 5, 2).

Предпосылкой для смены власти на Боспоре в 438/7 году вполне могло стать то обстоятельство, что симмахия Археанактидов выполнила свою историческую функцию - сплочения местных полисов для отражения скифской агрессии - и уже не отвечала новым экономическим требованиям. По мнению Е.А. Молева, полисы региона в конце второй трети V столетия до н.э. испытывали стенохорию, а институт симмахии плохо сочетался с задачей экспансии, прежде всего на Таманском полуострове, ради расширения хоры [12, с. 32]. И, действительно, как отмечает А.А. Масленников, все IV столетие и первая половина III В. до н.э. - эпоха расцвета сельских поселений Боспора [11, с. 42-43]. 
Не вдаваясь в детали и причины прихода Спартока к власти, первостепенно важно охарактеризовать форму правления, пришедшую на смену симмахии Археанактидов. В исследованиях последних лет оценка режима однозначна - тирания [5, с. 409-419; 8, с. 7, 42-45; 12, с. $34 ; 17$, с. 22,28$]$. Также единодушно отмечается качественный «скачок» в характере власти, приходящийся на правление Левкона I [5, с. 419; 8, с. 7, 42-43; 17, с. 24; 27, с. 178]. Однако попытки классификации правления первых Спартокидов как младшей тирании редки. - Так, М.И. Ростовцев полагал, что Боспорская тирания явление «своеобразное и единичное», не имеющая аналогий в античном мире (в том числе она не сопоставима с младшей тиранией) [15, с. 183]. Ю.Г. Виноградов сопоставляет сицилийский режим власти Дионисия и ранних Спартокидов, признает их тираническими, имеющими множество сходных тенденций, но термина «младшая тирания» в отношении Боспора не упоминает [5, с. 415-416]. Фролов Э.Д., на сегодняшний день крупнейший отечественный специалист в вопросах тирании, включив Спартокидов в список поздних тиранов, подробно проанализировал тиранию Клеарха в Геракле Понтийской и ни словом не обмолвился о северном побережье Понта [28, с. 124]. Э.Б. Петрова, проведя сравнительный анализ тираний на Боспоре и Кипре, приходит к выводу, что тирания Спартокидов начинается хронологически раньше младшей тирании в собственно Греции и поэтому может считаться ее провозвестницей [14, с. 17].

Интересная версия периодизации правления Спартокидов в конце V -начале IV вв. до н.э. была предложена А.А. Завойкиным. По его мнению, к первому этапу следует отнести события с 438/7 до 410/9-406/5 гг. до н.э. время утверждения тирании в рамках одного полиса. Второй период охватывает оставшиеся годы властвования Сатира I, когда к Пантикапею были присоединены Нимфей и ряд полисов на Таманском полуострове. А третий, завершающий этап формирования «территориальной державы» приходится на период правления Левкона I [8, с. 7].

При анализе религиозной политики трех первых Спартокидов было бы логично следовать этой периодизации, однако источниковая база не дает такой возможности. Поэтому два первых периода, предлагаемых А.А. Завойкиным, мы вынуждены объединить. Именно этот отрезок времени - в большей степени годы от переворота Спартока до архонтства Левкона - представляет для нас интерес. Поскольку мы рассматриваем Спартока, Сатира I и, отчасти, Левкона I именно как младших тиранов, что и попытаемся аргументировать примерами религиозной политики, свидетельствующими о сознательной трансформации ими сакральной практики полиса, превращению её в государственную идеологию.

Изменения в государственном устройстве Боспор- ского государства получили, прежде всего, отражение в титулатуре правителей. Исследователями было подмечено, что каждое территориальное приобретение Спартокидов сопровождалось изменением (уточнением) титула. Первая знаковая перемена происходит после покорения Левконом Феодосии в 360-е годы: официальный титул теперь звучит - «архонт Боспора и Феодосии» (КБН 1111) [4, с. 48]. Военный успех вызвал экономический подъем державы: по свидетельству Демосфена (adv. Lept., 33), была налажена широкая поставка зерна в Афины именно через феодосийский порт, который специально для этой цели был переоборудован. Афинянам в Феодосии Левконом была дарована ателия и можно предположить, что архонт Боспора полностью монополизировал поставки хлеба в Аттику не только из Феодосии, но и всех прочих подконтрольных ему портов Боспора [27, с. 168-169, 171].

Следующим шагом Левкона явилась экспансия в Синдике, в ходе которой был апробирован широкий спектр титулов: после захвата владений Гекатея, «царя синдов», как гласит надпись из Лабриса, Левкон стал дополнительно титуловаться «архонтом всей Синдики», затем «архонтом синдов» (или «Синдики» - КБН 6А) и, наконец, «царем синдов» [27, с. 164]. Как видно из эпиграфических свидетельств, с расширением экспансии титул разрастается: Левкон становится «архонтом Боспора и Феодосии, всей Синдики, меотов, торетов, дандариев, псессов» [22, с. 101], затем обращается к более привычному для местных племен титулу: «архонт Боспора, Феодосии, синдов, царь торетов, дандариев, псессов» (КБН 6А) [17, с. 28; 27, $175]$.

Сын его - Перисад - уже смог добиться прижизненного обожествления персоны царя (Strab. VII, 4, 4), возможно, по аналогии с Клеархом Гераклейским (тираном Гераклеи Понтийской в 364-352 гг. до н.э.), объявившим себя сыном Зевса и требовавшим божеских почестей (Just., XVI, 5, 7-11). Однако переломный момент в психологии боспорских эллинов, как подметил С.Р. Тохтасьев, наступает именно при Левконе I и преемнике его - Перисаде. Посвятительные надписи на постаментах статуй, во-первых, датируются именем правителя (что, впрочем, в русле традиции, ведь Спартокиды - архонты), а, вовторых, более половины всего объема текста занимает титулатура правителя (КБН 6, 6А, 7, 8, 1037, 1038, 1111). В то же время в посвящениях иноземцев, вторая тенденция отсутствует [27, с. 173-174]. Закономерным финалом эволюции титулатуры станет именование династов царями, что произойдет в начале III в. до н.э. при Спартоке III (КБН 19). Видимо, это общая тенденция начала эллинизма, так как Дионисий, тиран Гераклеи Понтийской, принял титул царя в 306 г. По мнению антиковедов, такой статус позволял чувствовать себя на равных в дипломатических переговорах с царями эллинистических государств, например, Митридатидами Понтийскими 
или Птолемеями) [17, с. 28].

Таким образом, эволюция титулатуры ранних Спартокидов позволяет сделать несколько важных выводов. Во-первых, они действительно тираны младшего поколения, ибо титул правителя изменяется часто на протяжении полувека и отражает территориальный рост государства, причем эволюционирует титул без санкции народного собрания. Во-вторых, на раннем этапе формирования державы титулы для варварской и эллинской ее частей различны, хотя исследователи отмечают стремление Спартокидов нивелировать статус своих подданных. Итогом эволюции титула станет провозглашение менее чем через столетие Спартока III царем (КБН 19).

Не менее знаковыми являются изменения пантеона формирующейся державы. В частности, знаменателен отход Левкона I от почитания Аполлона с эпиклезой Иетрос. - После победы над Феодосией он обращается к проблемам в Синдике и устанавливает в Лабрисе стелу, посвященную Фебу Аполлону (SEG, XLIII, 515) [4, с. 5]. T.B. Блаватская, опубликовавшая данный текст, считала, что в Лабрисе существовало святилище Феба Аполлона [1, с. 41]. Ю.Г. Виноградов, напротив, отрицал существование храма Феба, по крайней мере, в городской черте Лабриса, и полагал, что стела была адресована все-таки Иетросу, покровителю Боспорского государства. Эпиклеза Феб появилась, по мнению исследователя, намеренно, дабы акцентировать внимание на функции Аполлона, как бога, карающего преступления [4, с. 18-19]. Данные археологии о присутствии святилища Феба Аполлона в данной местности весьма невнятны [13, с. 40-43]. Однако интереснее другой факт - находка вотивной статуи Фебу, относящейся к правлению преемника Левкона Перисада (КБН 113), который первым из Спартокидов был обожествлен. Таким образом, «повышение ранга» Аполлона от Иетроса, ассоциировавшегося с временами равенства первопроходцев, к Фебу «победоносному» не является ли свидетельством автократических тенденций правителей Боспора? А поскольку поклонение Иетросу в Пантикапее, Гермонассе, Фанагории, то есть на территориях, давно освоенных эллинами, глубоко укоренилось, о чем свидетельствуют посвятительные надписи Аполлону Врачу, датированные IV веком до н.э. (КБН 6, 10, 25, 974, 991, 1037-1039, 1042, 1044). Не было ли естественным начать внедрение новой эпиклезы (культа) с окраинных территорий государства, воспользовавшись военным успехом?

Можно предположить, что акцентирование солярной стороны культа Аполлона, с расширением экспансии на азиатском Боспоре, было сделано намеренно, как уклонение в сторону иранских верований, где Митра являлся богом света, правды и справедливости, покровительствующим воинам, дарующим победу [19, с. 411]. -
Последнее обстоятельство также было на руку династии успешных завоевателей: представители старшей и младшей тираний использовали военные победы для популяризации своего режима.

Действительно, скифо-сарматской и синдо-меотской среде было близко и понятно поклонение всаднику, конному герою, олицетворявшему бессмертие, торжество жизни и светлого начала. Здесь паредром богинь, покровительствующих земледелию, выступал, в частности, Аполлон-Гелиос [2, с. 29; 19, с. 420]. Изображения всадника в Причерноморье известны с IV в. до н.э., а особенное распространение они получат во II-I вВ. до н.э. В варварской и эллинской среде он воспринимался с различными акцентами, однако, в целом, выступал как синкретический образ Аттиса-Митры-Аполлона [19, с. 426-427].

Представляется уместным привести мнение антиковедов о верованиях жителей региона в чуть более поздний период. - Анализируя синкретический пантеон Понтийско-Боспорского царства времени Митридатидов, С.Ю. Сапрыкин и А.А. Масленников отмечают, что «основные постулаты ирано-малоазийских религиозных представлений были одинаково понятны ираноязычным сарматам или скифам, выходцам из Малой Азии, нахлынувшим на Боспор при Митридатидах, а также грекам, сопоставлявшим с иранскими богами собственных, близких им по значению и функциям... Идея торжества светлого начала, приобщения богами их почитателей к бессмертному бытию, тесно смыкалась с официальной идеологией Митридатидов и их преемников, в основе которой лежало обожествление царства и правящей в нем династии. Сам же царь воспринимался как защитник от злых и враждебных сил, то есть темного начала, как защитник, эвергет и сотер-спаситель... Из этого вытекает богоизбранность повелителей и стремление сделать их бессмертными для подданных, что особенно характерно для культов царей Фарнака и Митридата Vl» [19, с. 440].

Таким образом, смена эпиклез Аполлона, верховного божества эллинов региона, в правление ранних Спартокидов есть знаковый момент в переориентации их политики. В начале династии, при Спартоке и Сатире I, еще витает идея существования режима в форме симмахии, но, по мере усиления единоличной власти, чему в немалой степени способствуют военные успехи и сближение с Афинами, начинается трансформация «союза» В единое государство. Столь стремительная, уложившаяся в полвека (от Спартока к Левкону І, включительно), эволюция государственного устройства от симмахии, через тиранию, к монархии не могла не повлечь трансформации пантеона, не потребовать идеологического обоснования изменений.

О стремлении Спартокидов легитимировать свое положение на международном уровне свидетельствуют их 
взаимоотношения с Афинами, крайне заинтересованными в стабильных поставках зерна. Характерен факт, что с ослаблением афинского полиса интерес боспорских правителей к продолжению контактов резко ослабевал. Интенсивность экономических и, как следствие, политических и культурных связей Причерноморья с Афинами в V-III вв. до н.э. на сегодняшний день является фактом, не требующим доказательств. Для Боспора Киммерийского, в правление Спартокидов, эти контакты выражались в поставках зерна в Аттику [10, с. 110-111], за что Афины оказывали «союзнику», а точнее, правящей династии, всемерную политическую поддержку. Режим «наибольшего благоприятствования» формировался обеими сторонами, и афинской, и боспорской.

Необходимо отметить, что после захвата власти Спартоком, был двадцатилетний период (до 410-406 гг.), когда отношения Афин и Пантикапея были весьма натянутыми. Это объяснялось их политической конфронтацией, возникшей после экспедиции Перикла в Понт, когда часть полисов Боспора вошла в состав Архэ, по-видимому, опасаясь экспансии Пантикапея. Ситуация изменилась в конце Пелопоннеской войны, когда Афины обратились за продовольственной помощью к Сатиру, de facto, предав своих боспорских союзников [8, с. 39-40].

Боспорские правители, начиная с 389 г. до н.э., после смерти Сатира I, приходя к власти, спешили отправить посольства в Афины, которые должны были подтвердить нацеленность Спартокидов на продолжение дружественного курса в отношении афинского полиса (IG, II, 212; МИС, 3). Заинтересованные в получении боспорского зерна, афиняне даровали царям права гражданства и освобождение от налогов (Dem., XX, 30), помимо этого на акрополе и агоре устанавливались статуи Сатира I, Горгиппа, Перисада I, а из более поздних правителей - Спартока III (IG, II, 653, 1008; МИC, 4, 42). Мраморные стелы с декретами в честь боспорских царей устанавливались в Пирее (Dem., XX, 36; IG, II, 212; MИC, 3). Пожалуй, в наивысшей степени благорасположение афинян проявлялось в награждении владык Боспора золотыми венками, которое происходило в ходе Панафинейских игр. Первым такой почести был удостоен Сатир I, посвятивший свой венок храму Афины, покровительницы игр, с надписью, что это дар Сатира. Далее, на протяжении всего IV века, на каждых Панафинеях провозглашалось об увенчании боспорских царей золотыми венками «за доблесть и благорасположение к афинскому народу». Изготовляя для Спартока II и Перисада I венки стоимостью в тысячу драхм, афиняне заранее нанесли на них текст дарственной надписи, ставший традиционным, в котором только менялись имена царей (IG, II, 212; MИC, 3) [20, c. 134]. Столь дружественные сношения полиса-гегемона Эллады и Боспорского государства наталкивают на аналогию с политикой младших тиранов, для которых важен был не столько признание их согражданами, сколько по-

\section{литическим союзником.}

В свою очередь, Спартокиды используют ради укрепления своей власти, религиозный фактор, связанный с верованиями афинян. В их правление происходит акцентированная поддержка культа Деметры, признанным центром которого в эту эпоху был Элевсин. Несомненно, что первоначально культ был перенесен апойками из Милета, но форма его отправления и содержание уже в конце V века до н.э., а тем более в IV веке, все более копирует Элевсинские мистерии. По мнению А.С. Русяевой, для Афин культ Деметры был «своеобразным политическим инструментом, направленным на то, чтобы с помощью подвластного им Элевсина привлекать на свою сторону элиту многих государств и получать как можно больше хлеба» [16, с. 320].

Такая переориентация Спартокидами боспорского пантеона, на наш взгляд, преследовала двоякую цель. Во-первых, противопоставление Деметры Аполлону, культ которого был традиционно аристократическим. Во-вторых, с покорением оседлых племен азиатского побережья Боспора, вводимый здесь культ Деметры наилучшим образом сочетался с традиционным почитанием варварами богинь, олицетворявших плодородие [16, с. 320-321].

Влияние религии афинского полиса несомненно сказывалось на мировоззрении боспорян, в связи с их частыми посещениями Афин и возникавшими родственными отношениями (Aeschin., III, 71). С.А. Жебелев предположил, что на рубеже V-IV вв. до н.э. между двумя государствами существовало соглашение об эпигамии [7, с. 192]. Многие граждане Боспора и Афин были связаны, в силу коммерческих интересов, узами гостеприимства (દ́́voc патріко́c) (Isocr., XVII, 43; Dem., XXXIV, 23). Отпрыски видных семей Боспора стремились получить образование в городе, который считался «школой всей Эллады» (Thuc., II, 41, 1) и «пританеем мудрости» (PI. Prot., 24) $[20$, с. $136-138,142]$.

Находки в Пантикапее свидетельствуют о влиянии Афин и в сфере культуры. Так, еще в V веке афинские скульпторы исполнили для столицы Боспора мраморный алтарь или базу статуи с вереницей шествующих женщин. В IV веке до н.э. они изваяли из мрамора статую Диониса и огромную портретную статую кого-то из семьи Спартокидов [3, с. 89, рис. 27; 21, илл. 16, 18]. По мнению М.В. Скржинской, крупные заказы вполне могли финансироваться из государственной казны. Например, изображения божеств для храмов, статуи граждан, оказавших особые услуги государству и архитектурные детали для украшения храмов и общественных зданий $[20$, с. 138$]$.

Как известно, для представителей младшей тирании 
не свойственно стремление к строительству крупных культовых сооружений, что объясняется их дистанцированием от сакральной практики гражданской общины. Для времени Спартока I и Сатира I данные раскопок в Пантикапее - столице династии - не свидетельствуют о возведении здесь храмов. Предположительно Сатиром здесь могла быть построена резиденция преемников Археанактидов, служившая местопребыванием и Левкона. И именно при Левконе I и его сыновьях (Спартоке II и Перисаде I), когда тирания эволюционирует к монархии, в середине - третьей четверти века, на акрополе сооружается грандиозный дворцовый ансамбль, а рядом дворцовый (курсив наш - Л.Т.) антовый храм. В это же время отмечается активное строительство культовых и общественных зданий в городе [8, с. 14-15]. То есть, активизация в возведении культовых, в первую очередь, построек, долженствующая иметь место, по крайней мере, при Сатире I, хронологически смещена в период, соответствующий поздней тирании - правлению Левкона и его сыновей.

Выказывание покровительства людям искусства яв- ляется характерной чертой старшей тирании. Но на Боспоре мы вновь обнаруживаем такие тенденции лишь в IV в. до н.э. - По-видимому, при Левконе, Перисаде и Евмеле велись исторические хроники. По крайней мере, отдельные эпизоды их правления, особенно борьба за власть сыновей Перисада, были освещены неизвестным историком из Пантикапея [9, с. 88].

Таким образом, при ранних Спартокидах происходила эволюция титулатуры правителей, апогеем чего стало обожествление Перисада І. Имел место процесс если не слияния, то, по крайней мере, сближения эллинских и местных божеств, что проявлялось в усилении культа Деметры и смены эпиклезы Аполлона с Иетроса на Феба. - Аполлон с солярной эпиклезой вполне мог ассоциироваться, например, с Митрой. В ипостаси Феба или Гелиоса он был близок племенам азиатского Боспора, а это способствовало укреплению здесь власти Спартокидов уже в качестве царей. Такие изменения в религии позволяют в целом дефинировать власть ранних Спартокидов как младшую тиранию.

\section{ЛИТЕРАТУРА}

1. Блаватская Т.В. Посвящение Левкона I // РА. - 1993. - № 2. - С. 34-48.

2. Блаватский В.Д. Воздействие античной культуры на страны Северного Причерноморья (IV в. до н.э. - III в. н.э.) // СА. - 1964. - № 4. - C. $13-29$.

3. Блаватский В.Д. Пантикапей. - М.: Изд-во АН СССР, 1964. - 232 с.

4. Виноградов Ю.Г. Левкон, Гекатей, Октамасад и Горгипп (Процесс интеграции Синдики в Боспорскую державу по новелле Полиэна (VIII, 55) и вотивной эпиграмме из Лабриса) // ВДИ. - 2002. - № 3. - С. 3-22.

5. Виноградов Ю.Г. Полис в Северном Причерноморье // Античная Греция. Т. 1. Становление и развитие полиса. Под ред. Е.С. Голубцовой и др. - М.: Наука, 1983. - С. 366-420.

6. Виноградов Ю.Г. Синопа и Ольвия в V В. до н.э. Проблема политического устройства // ВДИ. - 1981. - № 2. - С. $65-90$.

7. Жебелев С.А. Северное Причерноморье. Исследования и статьи по истории Северного Причерноморья античной эпохи. - М.-Л.: Изд-во АН СССР, 1953. $388 \mathrm{c}$.

8. Завойкин А.А. Образование Боспорского государства. Археология и хронология становления территориальной державы. Автореф. дис....д.и.н. M., 2007. -54 c.

9. Зубарь В.М., Русяева А.С. На берегах Боспора Киммерийского. - Киев: ИД «Стилос», 2004. - 239 с.

10. Кузнецов В.Д. Афины и Боспор: хлебная торговля // РА. - 2000. - № 1. -С. 107-120.

11. Масленников А.А. Эллинская хора на краю ойкумены. Сельская территория европейского Боспора в античную эпоху. - М.: Индрик, 1998. - 301 с.

12. Молев Е.А. Спарток и первые Спартокиды на Боспоре // АМА. - Вып. 10. - Саратов, 1999. - С. 30-37.

13. Новичихин А.М. Клеймо на фрагменте сероглиняного сосуда с Семибратнего городища // ВДИ. - 2006. - № 3. - С. $40-43$.

14. Петрова Э.Б. Боспор и Кипр: опыт сопоставления двух тиранических режимов // АМА. - Вып. 10. - Саратов, 1999. - С. $12-35$.

15. Ростовцев М.И. Государство и культура Боспорского царства. Государство и социальный строй эпохи Спартокидов // ВДИ. - 1989. - № 2. - С. $183-197$.

16. Русяева А.С. Религия понтийских эллинов в античную эпоху: Мифы. Святилища. Культы олимпийских героев. - Киев: ИД «Стилос», 2005. - 559 с.

17. Сапрыкин С.Ю. Боспорское царство: от тирании к эллинистической монархии // ВДИ. - 2003. - № 1. - С. 11-35.

18. Сапрыкин С.Ю. Гераклея Понтийская и Херсонес Таврический. Взаимоотношения метрополии и колонии в VI-I вв. до н.э. - М.: Наука, $1986 .-248$ с.

19. Сапрыкин С.Ю., Масленников А.А. Люди и их боги: Религиозное мировоззрение в Понтийском царстве // Человек и общество в античном мире. Под ред. Л.П. Маринович. - М.: Наука, 1998. - С. 398-440.

20. Скржинская М.В. Ольвиополиты и боспоряне в Афинах // ВДИ. - 2002. - № 2. - С. 133-143.

21. Соколов Г.И. Античное Причерноморье. Памятники архитектуры, скульптуры, живописи и прикладного искусства. - Л.: Аврора, 1973. - 191 с.

22. Соколова 0.Ю., Павличенко Н.А. Новая посвятительная надпись из Нимфея // Hyperboreus. - 2002. - Т. 8. - Ч. 1. - С. 99-121.

23. Суриков И.Е. Греческий полис архаический и классической эпох // Античный полис. Курс лекций. - М.: Русский Фонд Содействия Образованию и Науке, 2010. -240 c. 


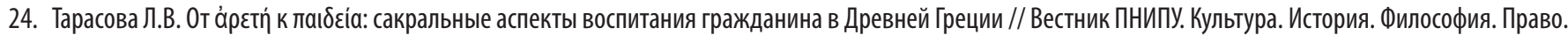
- 2017. - № 1. - Пермь: Изд-во ПНИПУ, 2017. - С. 45-53.

25. Тарасова Л.В. Религиозная политика ранней греческой тирании // Исторические, философские, политические и юридические науки, культурология и искусствоведение. Вопросы теории и практики. - Тамбов: Грамота, 2017. - № 7 (81). - С. 185-188.

26. Тарасова Л.В. Сакральные аспекты кодификации права в древней Греции // Современная наука: актуальные проблемы теории и практики. Серия: Гуманитарные науки. - 2017. - № 6. - С. 49-53.

27. Тохтасьев С.Р. Боспор и Синдика в эпоху Левкона I (Обзор новых эпиграфических публикаций) / ВДИ. - 2004. - № 3. - С. $144-180$.

28. Фролов Э.Д. Младшая тирания // Античная Греция. Кризис полиса. Т. ІІ. - М., 1983. - С. 121 - 156.

(c) Тарасова Любовь Валерьевна (tarlv@mail.ru).

Журнал «Современная наука: актуальные проблемы теории и практики»

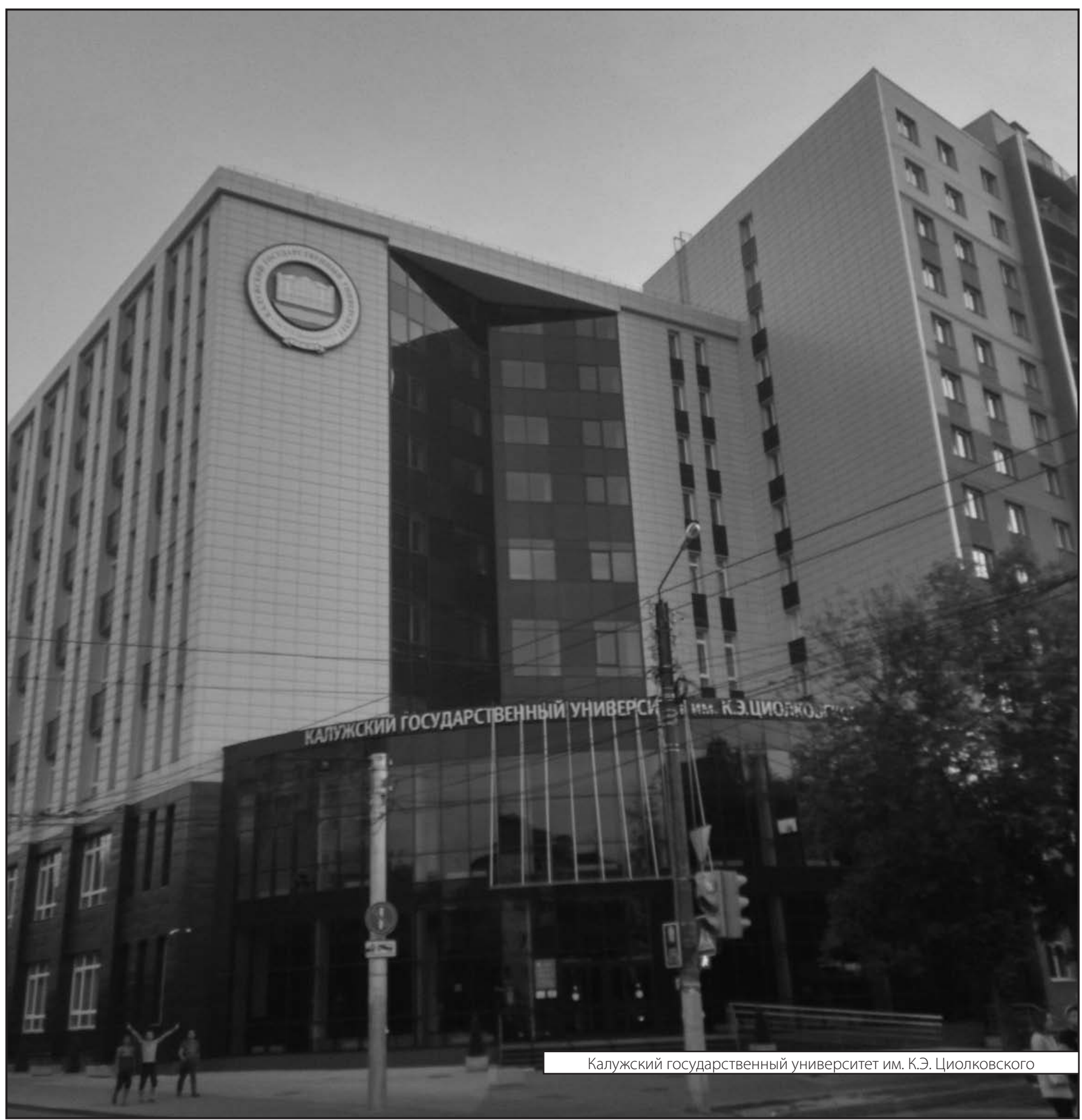

